
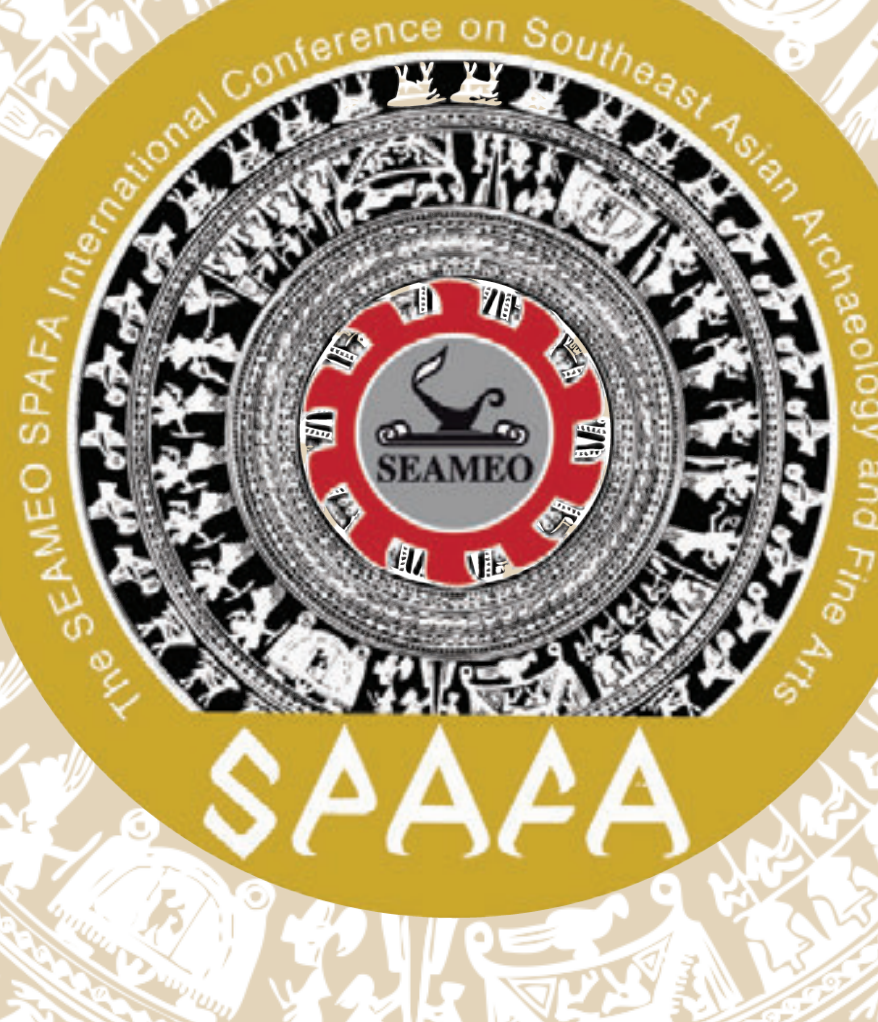
SPAFACON2021 is published by SEAMEO SPAFA, the Regional Centre for Archaeology and Fine Arts established by the Southeast Asian Ministers of Education Organization. SEAMEO SPAFA focusses on archaeology and fine arts in Southeast Asia, and promotes awareness and appreciation of the cultural heritage of the region. Its member-countries are Brunei, Cambodia, Indonesia, Lao PDR, Malaysia, Myanmar, the Philippines, Singapore, Thailand, Timor-Leste, and Vietnam; and its associate member-countries are Australia, Canada, France, Germany, the Netherlands, New Zealand, Spain and the United Kingdom. 


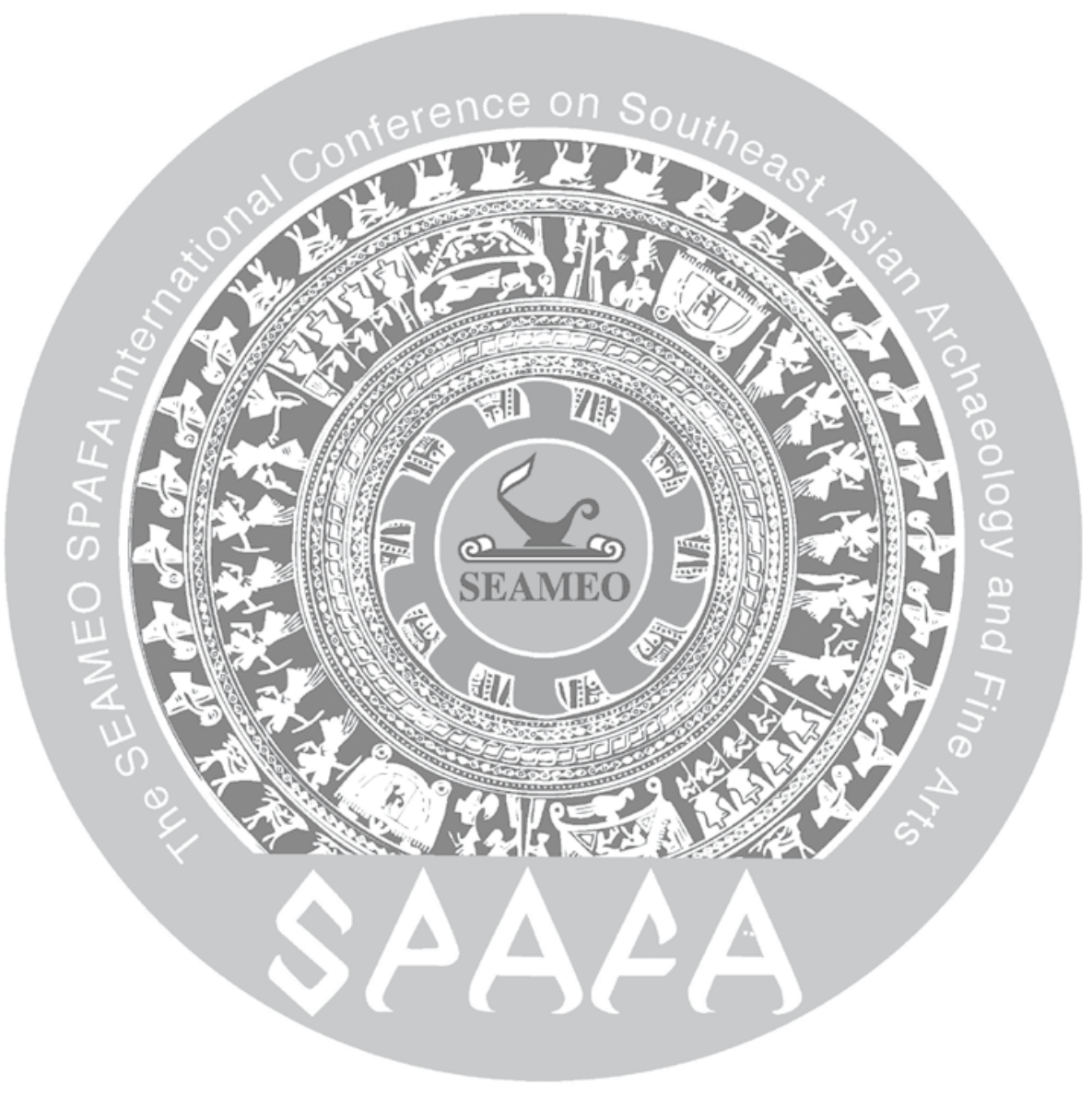

SPAFACON2021

Papers from the SEAMEO SPAFA International Conference on SOUTHEAST ASIAN ARCHAEOLOGY AND FINE ARTS

13 - 17 December 2021

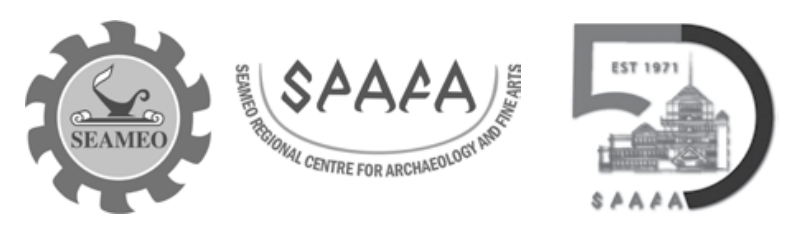


2021 SEAMEO SPAFA

ISBN: 978-616-7961-55-2

ISBN (e-book): 978-616-7961-54-5

DOI 10.26721/spafa.pqcnu8815a

\section{Publisher}

SEAMEO SPAFA Regional Centre for Archaeology and Fine Arts

81/1 Sri Ayutthaya Road, Dusit

Bangkok 10300, Thailand

Tel: +66 (0) 22804022 to 9

Fax: +66 (0) 22804030

www.seameo-spafa.org

E-mail: spafa@seameo-spafa.org

\section{Editor}

Dr Noel Hidalgo Tan

\section{Organizing Committee}

Mrs Somlak Charoenpot

Ms Vassana Kerdsupap

Mr Kanal Khiev

Mr Ean Lee

Ms Gabrielle Anne Mangaser

Dr Hatthaya Siriphatthanakun

Ms Ratchaporn Tesjeeb

Mr Patrick Xia Linhao

Dr Noel Hidalgo Tan

\section{(c) (1) (2)}

Copyright in the volume as a whole is vested in SEAMEO SPAFA, and copyright in the individual chapters also belong to their respective authors and licensed under Creative Commons CC BY-SA 4.0. To view a copy of this license, visit https://creativecommons. org/licenses/by-sa/4.0/

The papers in this publication have not been peer-reviewed and may thus contain preliminary findings, errors, or information that has yet to be endorsed by the relevant academic community. The views expressed in the publication do not necessarily reflect the opinions or policies of SEAMEO SPAFA. 


\section{Title}

\section{CONTENT}

\begin{tabular}{|c|c|c|}
\hline Title & Author & Page \\
\hline \multicolumn{3}{|l|}{ Introduction } \\
\hline $\begin{array}{l}\text { A Historiography of Settlement Archaeology in Southeast } \\
\text { Asia, with Emphasis on the Pre-industrial State Formations }\end{array}$ & Gyles Iannone & 1 \\
\hline $\begin{array}{l}\text { Ocean Imperatives: analysing shipping infrastructure for the } \\
\text { study of maritime networks in Southeast Asia }\end{array}$ & Veronica Walker Vadillo & 17 \\
\hline $\begin{array}{l}\text { Forms of government and local community participation in } \\
\text { the management of cultural World Heritage sites in Southeast } \\
\text { Asia }\end{array}$ & Vithaya Arporn & 24 \\
\hline $\begin{array}{l}\text { Cultural interaction between Việt Nam and Southeast Asian } \\
\text { nations in the } 15^{\text {th }}-16^{\text {th }} \text { centuries: An overview of pottery } \\
\text { items from ancient shipwrecks on display at the Museum of } \\
\text { History in Hồ Chí Minh City }\end{array}$ & $\begin{array}{l}\text { Phạm Ngọc Uyên, } \\
\text { Nguyễn Thị Tú Anh }\end{array}$ & 29 \\
\hline $\begin{array}{l}\text { Sequential Least-Cost Path Sailing Model for Early } 17^{\text {th }} \\
\text { Century South China Sea: Digitally Navigating the Selden } \\
\text { Map of China }\end{array}$ & Wesa Perttola & 40 \\
\hline $\begin{array}{l}\text { The Prevailing Art and Tradition of Intentional Dental } \\
\text { Modification in Prehistoric Southeast Asia }\end{array}$ & Maria Kathryn N. Purnell & 56 \\
\hline $\begin{array}{l}\text { The Still Unexplored Parts of Southeast Asian Archaeology: } \\
\text { Colonial Archaeology Singapore }\end{array}$ & Sxuann Sim & 74 \\
\hline $\begin{array}{l}\text { Khao San Dam: The Archaeological Evidence of Burnt Rice } \\
\text { Festival in Southern Thailand }\end{array}$ & Pakpadee Yukongdi & 83 \\
\hline $\begin{array}{l}\text { Before Bagan: Using Archaeological Data Sets to Assess the } \\
\text { Traditional Historical Narrative }\end{array}$ & $\begin{array}{l}\text { Scott Macrae, Gyles } \\
\text { Iannone, Kong Cheong, } \\
\text { Pyiet Phyo Kyaw }\end{array}$ & 96 \\
\hline The Rock Art in Kinta Valley, West Malaysia: A synthesis & $\begin{array}{l}\text { Chaw Yeh Saw } \\
\text { Hsiao Mei Goh }\end{array}$ & 114 \\
\hline $\begin{array}{l}\text { New Archaeological Discoveries: Gates and Turrets of } 16^{\text {th }} \\
\text { Burmese Royal Capital of Hamsāvatī }\end{array}$ & Thaw Zin Latt & 131 \\
\hline $\begin{array}{l}\text { A preliminary survey of Chinese ceramics in Champa } \\
\text { archaeological sites }\end{array}$ & Do Truong Giang & 148 \\
\hline $\begin{array}{l}\text { A Study on the Structure and Significance of the North } \\
\text { Sanctuary at Western Prasat Top }\end{array}$ & $\begin{array}{l}\text { SATO Yuni, TAMURA } \\
\text { Tomomi, SUGIYAMA } \\
\text { Hiroshi, LAM Sopheak, } \\
\text { SOK Keo Sovannara, } \\
\text { LOEUNG Ravattey, ROS } \\
\text { Visoth }\end{array}$ & 166 \\
\hline The funeral cave of Laang Spean & $\begin{array}{l}\text { Valéry Zeitoun, } \\
\text { Heng Sophady, Hubert } \\
\text { Forestier }\end{array}$ & 173 \\
\hline
\end{tabular}




\begin{tabular}{|c|c|c|}
\hline Title & Author & Page \\
\hline $\begin{array}{l}\text { The Bronze Age People of Ban Kao: A Preliminary Analysis } \\
\text { of the Human Remains from Ban Ta Po Archaeological Site, } \\
\text { Western Thailand }\end{array}$ & $\begin{array}{l}\text { Naruphol } \\
\text { Wangthongchaicharoen, } \\
\text { Supamas Duangsakul, } \\
\text { Pira Venunan, Sukanya } \\
\text { Lertwinitnun, Siriyupon } \\
\text { Tubpenthai }\end{array}$ & 187 \\
\hline The Mt. Popa Watershed and Bagan’s Bronze-Iron Age & Elizabeth Moore & 195 \\
\hline $\begin{array}{l}\text { After } 30 \text { Years and During a Pandemic: Pottery Production } \\
\text { and Distribution in Bagacay, Talibon in the Island of Bohol in } \\
\text { the Philippines }\end{array}$ & $\begin{array}{l}\text { Rhayan Gatbonton } \\
\text { Melendres }\end{array}$ & 205 \\
\hline $\begin{array}{l}\text { Heritage Education in Myanmar - developing resilience and } \\
\text { sustainability through community engagement }\end{array}$ & $\begin{array}{l}\text { Su Su, Win Thant Win } \\
\text { Shwin, Ohnmar Myo, } \\
\text { Charlotte Galloway, } \\
\text { Elizabeth Moore }\end{array}$ & 220 \\
\hline $\begin{array}{l}\text { As my father said: Traditional boatbuilding in Pasuruan, East } \\
\text { Java }\end{array}$ & $\begin{array}{l}\text { Agni Mochtar, Putri } \\
\text { Taniardi, R. Ahmad } \\
\text { Ginanjar Purnawibawa }\end{array}$ & 234 \\
\hline $\begin{array}{l}\text { Tangibility-Intangibility on UNESCO World Heritage } \\
\text { Baroque Philippine Churches: the Spirit of Place and Its } \\
\text { Collective Memory }\end{array}$ & Hee Sook Lee-Niinioja & 241 \\
\hline $\begin{array}{l}\text { Myinkaba village Bagan: The Resilience of Traditional } \\
\text { Knowledge and Culture }\end{array}$ & Theint Aung & 254 \\
\hline $\begin{array}{l}\text { Thai Carpentry Knowledge Transmission: Development of } \\
\text { Traditional Apprenticeships in a New Context }\end{array}$ & Nichamon Hiranpruek & 262 \\
\hline $\begin{array}{l}\text { The Factors of Market Success and Failure of Contemporary } \\
\text { Artists from ASEAN countries }\end{array}$ & Dr Rémy JARRY & 268 \\
\hline $\begin{array}{l}\text { The Forgotten Women: Investigating the Absence of the } \\
\text { Female Artist from Traditionally Male-Centric Southeast } \\
\text { Asian Contemporary Art Historical Narratives }\end{array}$ & Vasanth Narayanan & 279 \\
\hline As One With Nature: Southeast Asian Aesthetic Expressions & Victor R. Savage & 289 \\
\hline $\begin{array}{l}\text { The Series Of Archaeological Dances: A Historical Study and } \\
\text { Dance Moves Recording With Labanotation }\end{array}$ & Dharakorn Chandnasaro & 309 \\
\hline $\begin{array}{l}\text { Musical Instruments on the 16th century bas reliefs in } \\
\text { the North Gallery-East Wing of Angkor Wat : Dating and } \\
\text { Significance }\end{array}$ & Arsenio Nicolas & 324 \\
\hline $\begin{array}{l}\text { Photography in Indonesian Archaeology of the } 19^{\text {th }} \text { to the } \\
\text { Early } 20^{\text {th }} \text { Century }\end{array}$ & $\begin{array}{l}\text { Ahmad Kholdun Ibnu } \\
\text { Sholah }\end{array}$ & 356 \\
\hline $\begin{array}{l}\text { Old Burmese weights were not opium weights. They were } \\
\text { weights. What else do we know about them? }\end{array}$ & Bob Hudson & 369 \\
\hline $\begin{array}{l}\text { Religious Object" Exhibition in the Context of Cultural } \\
\text { Change and Covid-19 Social Distancing (Case studies of } \\
\text { Khmer's Nagar boat in the South of Vietnam) }\end{array}$ & Phạm Thị Thủy Chung & 381 \\
\hline
\end{tabular}




\section{Title}

Author

Page

Creativity and Innovation in Cultural Heritage Management in Plunturan Village, Pulung District, Ponorogo Regency,

Ria Kusuma Wardani, S.Pd.

East Java Province of Indonesia Towards Tourism Village

Beyond the artefact : promoting technology

Cécile de Francquen 407

Indonesian Museum after New Order Regime: The

Representation that Never Disappears

Ayu Dipta Kirana, Fajar

Aji Jiwandono

Geological Museum Innovations to Dealing with Covid-19 Ifan Yoga Pratama Suharyogi, Agustina Djafar, Rahajeng Ayu

Pandemic 


\section{INTRODUCTION}

This volume contains the extended abstracts from the papers presented at the SEAMEO SPAFA International Conference on Southeast Asian Archaeology and Fine Arts, which was held online from 13 to 17 December 2021. Also known as the SPAFACON2021, this conference was organised online due to the pandemic. Despite the disruption brought about by Covid-19 to our in-person events, training programmes and field research, it is heartening to see that archaeology and cultural heritage has continued under new modes of communication and collaboration.

This fourth iteration of the SPAFACON is also scheduled a year earlier than our usual triennial cycle to commemorate the 50th anniversary of SEAMEO initiating a centre dedicated towards archaeology and the fine arts. Over the past year, SPAFA has also been highlighting this legacy of international cooperation and capacity-building by sharing our photographic archives on our social media.

I am delighted by the high level of enthusiasm and intellectual curiosity brought by the participants to the conference. During our call for papers we received close to 90 submissions, but owing to the pressures of time and the online format, we were only able to accept 34 papers for the conference. The variety of papers present here, although a small set compared with our usual proceedings, reflects the breadth of the centre's ambit covering not just archaeology, but also performing arts, visual arts, museum studies, and other aspects of Southeast Asian cultural heritage.

I would like to thank all the participants, without whom this conference would not be possible in its present form, in particular, our Governing Board members who represent every country in Southeast Asia, and to the Ministry of Culture, Thailand and the Ministry of Education, Thailand for their long-standing support of SEAMEO SPAFA and its activities.

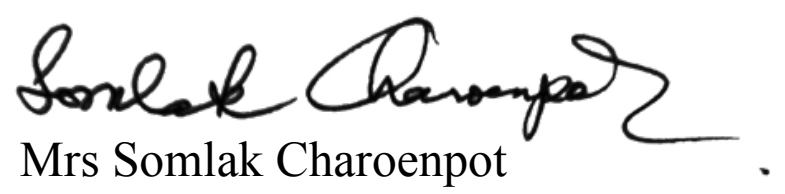

Centre Director

SEAMEO SPAFA 


\title{
Thai Carpentry Knowledge Transmission: Development of Traditional Apprenticeships in a New Context พัฒนาการทางรูปแบบกรส่งต่อองค์ความรู้ในการสร้างอาคารไม้ไทยโบราณใน บริบทปัจจุบัน
}

10792/pqcnu8815a-22

Nichamon Hiranpruek

PhD Student, Graduate School of Asia-Pacific Studies, Waseda University jan@ruri.waseda.jp

\begin{abstract}
The shortage of highly skilled carpenters is an obstacle to the conservation of Thai wooden heritage. This article aims to explore the development of the Thai carpentry education system in order to analyse its nature and propose an effective method for conserving traditional knowledge. This research is based on interviews with relevant parties who work closely with traditional Thai wooden construction. Documentary research is also utilized to supplement data obtained from fieldwork. The findings suggest that apprenticeships make up the largest part of a carpenter's education. Although apprenticeships have transitioned from traditional to institutional, the essence of the education remains the same.
\end{abstract}

การวิจัยเรื่องพัฒนาการทางรูปแบบการส่งต่อองค์ความรู้ในการสร้างอาคารไม้ไทยโบราณในบริบทปัจจุบันเป็นการ ศึกษาโดยใช้ระเบียบวิจัยเชิงคุณภาพ มีวัตถุประสงค์ในการวิจัยคือศึกษาความเปลี่ยนแปลงของรูปแบบการศึกษา ในการวิเคราะห์หัวใจสำคัญในการเรียนรู้เพื่อนำเสนอแนวทางในการรักษาองค์ความรู้งานไม้อย่างยั่งยืน ผลการ วิจัยพบว่ารูปแบบการศึกษาพัฒนาจากการฝากตัวเป็นศิษย์สู่การเรียนรู้ในสถาบันศึกษาและที่ทำงาน แต่หลัก สำคัญในการเรียนรู้ยังอยู่ที่การฝึกฝนโดยตรงระหว่างทำงานเช่นเดิม

\section{Keywords}

carpenter; Thai traditional carpentry; traditional knowledge; knowledge transmission; apprenticeship ช่างไม้; อาคารไม้ไทยโบราณ; องค์ความรู้ดั้งเดิม; การส่งต่อองค์ความรู้; การฝึกหัดทักษะผ่านระบบศิษย์อาจารย์ 


\section{Introduction}

Traditional Thai wooden architecture is one of the most distinguished examples of Thailand's national heritage. Some of these traditional structures, including the Tamnak Daeng $^{l}$ and Ruen Tabkwan ${ }^{2}$, are conserved by governmental agencies, while others are protected by private owners, for instance, people who inherited the buildings from their ancestors. Newly built traditional houses with adaptive space are still popular to some extent, despite the spread of modern concrete houses. One of the primary concerns in the conservation of traditional wooden structures is the shortage of highly skilled carpenters who can perform the work necessary for building and maintaining them. Because tacit knowledge transmission relies mainly on learning through hands-on experience with a master, time and patience are required to perfect one's skills, but few people these days have such devotion. Despite the need to develop a new generation of carpenters, the issue has not received sufficient critical attention. Most previous studies of Thai carpentry have focused on design, form, and usability, but little is known about knowledge transmission. Therefore, this study aims to fill in the gap by focusing on the development of traditional carpentry apprenticeships.

The research data in this study is drawn from two main sources: interviews with relevant parties who work closely with traditional Thai architecture (i.e., architects working for the Thai Ministry of Culture, master carpenters, construction companies specializing in traditional architecture) and documentary research. The central question in this study asks how traditional apprenticeships have developed or evolved in the modern setting. The findings should offer important insights into the essence of learning traditional carpentry that can be utilized to propose a method for conserving traditional knowledge. However, this study does not cover traditional woodworking for decorative purposes such as Khrueang Yot ${ }^{3}$ and Chofa Bai-raka ${ }^{4}$. Rather, the scope of study is limited to traditional carpentry in the Rattanakosin period (1782-present), and throughout this paper the term "carpenter" refers to structural carpenters.

$1 \quad$ The royal residential buildings in the palace built during the reign of King Rama I.

2 One of the wooden residential buildings of the Sanamchan palace designed by Praya Wisawakamsinprasit, the renowned master artisan and architect during the reign of King Rama VI.

3 The pointy decorative ornament on the top of the roof, used exclusively for the king's buildings.

4 Decorative element for temple roofs and other decorative woodcarvings. 


\section{Traditional Apprenticeship and the Learning Process}

As in other traditional crafts, apprenticeships have long been the main learning format for traditional carpentry in Thailand. In general, apprentices ask a master to take them in and train them by allowing them to observe, imitate, and practice while working alongside the master. Sometimes, the master has to indulge the apprentice; given how much time the learning process requires, the apprentice is expected to repay the master by helping out with chores or other tasks (Artworks of Royal Artisans 2011, 13; N Saowanit 2017, personal communication, 22 June). In the past, techniques were usually passed down within the family, and certain families of artisans were famous for certain crafts. There are a few written records describing families that had mastered wood joinery for construction and the apprenticeship process they used. However, according to Pravet Limparungsri ${ }_{5}^{5}$ Sumran 2020) and an interview I conducted with Pramuk Banjerdsakun on 14 June 2018 , the most important process is repetitive training on site.

It is clear that the construction process is crucial for knowledge transmission. Thus, because the kings considered it their mission to cultivate traditional arts and craft (Phraratchadamrat top nai kan poet rongrian pho chang 1913: 2498-2501; Thiphakorawong (Kham Bunnag) 1916), they ordered several construction, restoration, and repair projects to create opportunities for royal court artisans to polish their skills and pass on their knowledge to their apprentices during the early Rattanakosin period (1782-1868). Both Naruporn Saowanit $^{6}$ (N Saowanit 2017, personal communication, 22 June) and Phahonchai Premjai $^{7}$ (P Premjai 2017, personal communication, 28 June) similarly noted the central role that the construction process plays for local carpenters. They explained that when wood and other local materials were the main building materials for houses, people in the community with basic construction skills would help each other build their homes. In addition, people with specific skills (e.g., carpenters, painters, stucco artisans) would help build basic infrastructures such as temples and other religious buildings as well as the bridges in their neighbourhood, thereby encouraging knowledge sharing within the community (Artworks of Royal Artisans 2011: 13).

5 Thai architectural specialist who was an apprentice of Phra Phrombhichitr, one of the most respected Thai master craftsmen. Pravet was given the title National Artist in the Visual Arts.

6 Naruporn Saowanit is a professional architect in the Office of Architecture, Department of Fine Arts, Ministry of Culture who has been in charge of various traditional Thai architecture projects.

$7 \quad$ Phahonchai Premjai is an architect and a founder of PO-D Architects. Apart from modern architecture, he also specializes in vernacular architecture and is in charge of Isan Village at Jim Thompson Farm (an outdoor north-eastern vernacular achitecture musuem which gathers various characteristic local timber houses) 


\section{Educational Institutes}

Traditional crafts were included in the formal education curriculum for the first time during the reign of King Rama VI. The Poh-Chang School ${ }^{8}$ was founded in 1913 to conserve traditional skills. Carpentry was originally a part of the curriculum but was later removed. There are also traditional Thai crafts and architecture programs offered in a fully hands-on learning format as Diploma/High Vocational formal education. However, most of these programs are not associated with traditional structural carpentry, focusing instead on decorative woodworking and modern carpentry. As for university-level architecture education, graduates of Chulalongkorn University who majored in traditional Thai architecture told me that although students in this program develop a comprehensive understanding of traditional Thai wood joints for construction, they would not be able to build a house themselves (N Saowanit 2017, personal communication, 22 June; S Wongsim 2019, personal communication, 5 Oct). In contrast, the School of Architecture at the Arsom Silp Institute of the Arts places a strong emphasis on hands-on learning. Apart from lectures, students are required to work at a construction site under the supervision of their professor. However, it is unclear whether graduates of this program are able to use traditional techniques.

\section{In-house Training}

Saowanit told me that since the position of royal court artisan was dissolved by the government, the private sector has been responsible for the construction of royal buildings as well as national heritage repair and restoration projects, under the supervision of the Department of Fine Arts (N Saowanit 2017, personal communication, 22 June). There are a few construction companies specialized in traditional Thai architecture. P.V.C. Likitkarnsrang (hereafter, P.V.C.) is one such company and it is widely celebrated for its expertise ${ }^{9}$. As for traditional Thai home builders, Sor Rauycharoen is a well-known corporation with more than 40 years of experience ${ }^{10}$. The present study collected data on the in-house training programs of P.V.C. and Sor Rauycharoen to illuminate carpenter training in the present day because both parties have a good track record of developing new generations of carpenters, although they have different approaches.

8 Current name: Poh-Chang Academy of Arts, Rajamangala University of Technology Rattanakosin

9 P.V.C. Likitkarnsrang has been entrusted with a slew of royal projects as well as the repair and restoration of national treasures. For instance, Phramerumas (temporary construction for royal cremation ceremony) of royal family members and Thai pavilion overseas.

10 Sor Rauycharoen's outstanding projects are for example Thai traditional house at Suan Pakkard Palace and Thai pavillion in Tel Aviv. 
Banjerdsakun, the master carpenter and founder of P.V.C, told me that he trains the apprentices himself. Some of the apprentices stay at the compound that includes his house and woodworking studio. There, they learn the basics before they start working at actual construction sites where they learn more advanced skills. He noted that although the hardship of training has been alleviated somewhat by modern electric tools, carpentry remains a tough skill to master, and he has to supervise his apprentices very closely. He also added that hands-on learning remains crucial because carpentry cannot be taught through words alone (P Banjerdsakun 2018, personal communication, 14 June).

In contrast to the in-house training provided by P.V.C. that resembles a traditional apprenticeship, Sor Rauycharoen has adopted a more adaptive approach based on the business background of Suk-ruai-charoen, the company's founder. She spent years teaching herself by observing carpenters while they were working on traditional Thai houses, and she even took measurements of houses she was interested in. Even though she could not build a house herself, she learned knowledge ${ }^{11}$ such as structure, proportion, and assembly well enough to work with carpenters and set up a training system. The carpenters of Sor Rauycharoen are divided into four groups according to task: general carpenter, wood-panel carpenter, roof-ornament carpenter, and assembly carpenter. Young carpenters are trained by a senior carpenter who possesses a higher level of skill (Chaiwong 2020). Despite differences in the details of categorizing, the organization is similar to how traditional carpentry roles were divided by task in the Krom Chang Sip Moo (traditional arts department) ${ }^{12}$.

Despite their differences, both companies currently face the same problem: a lack of new carpenters. Even though trainees do not have to request the master to take them in and they are paid a salary, the training takes at least 5 years, so many trainees quit and look for other work rather than committing to perfecting their skills.

\section{Preliminary Conclusions}

The objective of this study is to identify the development of traditional carpentry apprenticeships in order to grasp the core of the learning process. The findings to date have revealed that the format of learning has transitioned from living with one's master and working for compensation to two main approaches: learning in a formal school

11 She also received an honorary degree in traditional Thai houses and sometimes gives lectures on this subject.

12 Carpentry in the Krom Chang Sip Moo department used to be divided into various categories such as demolition carpenter, roof ornament carpenter, and wood-processing carpenter. 
or undergoing in-house training at a company. Although most institutional education programs provide a comprehensive understanding of Thai architecture, the lack of handson experience with skilled carpenters does not lead to mastery of the necessary skills. In contrast, in-house training follows a more traditional approach despite the shift in relationship from master and apprentice to employer and employee. Both of the companies examined in this study emphasize hands-on learning supervised by senior carpenters. This implies that the essence of the learning has not been affected by the format. Therefore, to conserve traditional carpentry techniques, it is important to highlight experiential learning and provide incentives for trainees to complete their studies.

\section{Reference}

Banjerdsakun, P (2018) Unpublished interview conducted by Nichamon Hiranpruek, June 14.

Chaiwong, Chatchanok. 2020. The Cloud. February 3. Accessed October 19, 2020. https://readthecloud.co/sor-ruaycharoen/.

Damrong Rajanubhab, Somdet phracaoborommawongthoe kromphraya (1916)

Phraratphongsawadan Krungrattanakosin Ratchakan Thi Song [Chronicle of the Second Reign of Rattanakosin]. Bangkok: Rongphim thai na saphan yotse. https://vajirayana.org/พระราชพงษาวดาร-กรุงรัตนโกสินทร-รัชกาลที่-๒ะ๕๖-เรื่องสร้างสวนขวา

Phraratchadamrat top nai kan poet rongrian pho chang [His majesty's speech on establishing Poh-Chang school] (1913). Royal Thai Government Gazette, no.30, 2498-2501.

Premjai, P (2017) Unpublished interview conducted by Nichamon Hiranpruek, June 28. Saowanit, N (2017) Unpublished interview conducted by Nichamon Hiranpruek, June 22.

Sumran, P (2020) Thai Architecture and Decorative Pattern by Buddhist Arts and Architecture Diciple Pravet Limparungsi. The Ten Books on Architecture by ASA,Vol.8. Bangkok: The Association of Siamese Architects under Royal Pratonage, 173.

The office of National Museums (2011) Artwork of Royal Artisan. Bangkok: Amarin Printing and Publishing, 13.

Wongsim, S (2019) Unpublished interview conducted by Nichamon Hiranpruek, 5 Oct. 